Available online on 15.7.2018 at http://ujpr.org
Universal Journal of Pharmaceutical Research
An International Peer Reviewed Journal
Open access to Pharmaceutical research

\title{
ANTIHYPERGLYCEMIC AND ANTI-OXIDANT POTENTIAL OF ETHANOL EXTRACT OF VITEX THYRSIFLORA LEAVES ON DIABETIC RATS Theodora Kopa Kowa $^{1}$ D, Nyemb Nyunai: ${ }^{*}$, Armelle Deutou Tchamgoue ${ }^{1}$ (D), Thierry Gilbert Nkoulou Tabi ${ }^{3}$ iD \\ ${ }^{1}$ Centre for Research on Medicinal Plants and Traditional Medicine, Institute of Medical Research and Medicinal Plants Studies (IMPM), P. O. Box 13033 Yaoundé, Cameroon. \\ ${ }^{2}$ Medical Research Centre, Institute of Medical Research and Medicinal Plant Studies (IMPM), P. O. Box 13033 Yaoundé Cameroon. \\ ${ }^{3}$ Department of Animal Biology and Physiology, University of Yaoundé I, P. O. Box 812 Yaoundé, Cameroon.
}

\section{ABSTRACT}

Objective: Vitex thyrsiflora Baker (Verbenaceae) is a glabrous under shrub that is widely distributed in Cameroon. Diabetes is characterized by chronic hyperglycemia, a source of increased oxidative stress and tissue oxidative damage. The objective of current study was to estimate the antihyperglycemic and anti-oxidant potential of ethanol extract of Vitex thyrsiflora leaves on diabetic rats

Methods: The antihyperglycemic effect of an ethanol extract of Vitex thyrsiflora leaves was investigated in normal male rats and streptozotocin induced diabetic male rats and its antioxidant potential was evaluated. After preparation of the extract, it was subjected to a phytochemistry screening, and tested on male rats made hyperglycemic in the Oral Glucose Tolerance Test (OGTT) and in streptozotocin diabetic rats. Glibenclamide $(10 \mathrm{mg} / \mathrm{Kg})$ was served as a positive control in both experiments. The evaluation of the antioxidant potential was done through the determination of the total polyphenols and total flavonoid contents, and by using the ferric reducing antioxidant power assay and the free radical scavenging activity on DPPH method.

Results: The results show that the extract contains alkaloids, flavonoids, steroids, saponins and phenolic compounds. The test on hyperglycemic rats in OGTT showed that, the extract was effective (at a dose of $200 \mathrm{mg} / \mathrm{Kg}$ ) to significantly decreased glucoseinduced hyperglycemia $(* * p<0.01)$. The extract was ineffective on streptozotocin induced diabetic rats. The study of the antioxidant potential showed that, polyphenols and flavonoids increase with the concentration of the extracts. $\mathrm{IC}_{50}$ value was found to be 65.97, based on the log (inhibitor) vs. normalized response-Variable slope.

Conclusion: FRAP appears to be significantly highly correlated with total polyphenols content and total flavonoids content. This shows that the ethanol extract of $V$. thyrsiflora leaves could be served to prevent acute hyperglycema, but not a chronic hyperglycemic state.

Keywords: Antihyperglycemic, antioxidant, diabetic rats, Vitex thyrsiflora.

Article Info: Received 2 May 2018; Revised 7 June; Accepted 4 July, Available online 15 July 2018

口焦起品 Cite this article-

Kowa TK, Nyemb N, Tchamgoue AD, Tabi TGN. Antihyperglycemic and anti-oxidant potential of ethanol extract of Vitex thyrsiflora leaves on diabetic rats. Universal Journal of Pharmaceutical Research 2018; 3(3): 1924.DOI: https://doi.org/10.22270/ujpr.v3i3.161

Address for Correspondence:

Nyemb Nyunaï, Medical Research Centre, Institut

Yaoundé, Cameroon. E-mail: nyunain@yahoo.fr

\section{INTRODUCTION}

The genus Vitex (Verbenaceae) is constituted by 250 species of small trees and shrubs which occur in tropical and subtropical regions ${ }^{1}$. Vitex thyrsiflora Baker (Verbenaceae) is a glabrous under shrub that is widely distributed in Cameroon ${ }^{2}$. This plant is reported to be useful in the treatment of orchitis ${ }^{2}$. The root barks are used in the treatment of stomach pains, sexual sterility and wounds ${ }^{3}$. Previous chemical investigations on the leaves and fruits resulted in the isolation of phytoedysteroids ${ }^{3}$. However, the investigation of some other Vitex species have resulted in the isolation of iridoids $^{4,5,6}$, diterpenes ${ }^{7,8}$, steroids ${ }^{9}$, flavonoids ${ }^{6}$ and triterpenoids ${ }^{9}$. Several of previous compounds isolated from Vitex genus have shown antioxidants activities $^{10,11}$. Among all secondary metabolites, phenolic antioxidants appear to be the most important since they have shown promising antioxidant activity in both in vivo and in vitro investigations. Plant phenolics are mainly classified into five major groups, phenolic acids, flavonoids, lignans, stilbenes and tannins ${ }^{12,13,14}$. The antioxidant activities of these compounds have been attributed to various mechanisms which have been established by various 
assay procedures ${ }^{15}$. Antioxidant activity has a fundamental role in cellular protection during an inflammation process. The identification of phytochemical compounds in plant species has been exploited in recent years, due to the growing popularity of herbal medicines and consumers growing enthusiasm for foods with bioactive characteristics that aid in preventing and fighting disease $\mathrm{e}^{\mathbf{1 6}, 17}$. Diabetes is characterized by chronic hyperglycemia, a source of increased oxidative stress and tissue oxidative damage. In particular, hyperglycemia promotes the glycation of proteins resulting in the formation of advanced glycation products (AGE). Thus antioxidant molecules appear as an opportunity for a strategy to fight not only against hyperglycemia, but also against complications related to diabetes mellitus ${ }^{18,19}$. Then, the objectives of this study based on these findings, was first to evaluate the antihyperglycemic effect of an ethanol extract of $V$. thyrsiflora leaves in glucose loaded rats and in STZdiabetic rats and second to determine the Total Polyphenols Content (TPC), Total Flavonoids Content (TFC), the Ferric Reducing Antioxidant Power Assay (FRAP) and the DPPH free radical scavenging assay of this extract.

\section{MATERIALS AND METHODS Experimental \\ Drugs and Chemicals}

Streptozotocin, quercetin and catechin were obtained from Sigma Chemicals (St. Louis, MO). Glibenclamide (Glycomin $\left.{ }^{\circledR}\right)$ was obtained from Strides Arcolat Ltd. Bangalore, India. All other chemicals used were of analytical grade. Spectrophotometric measurements were done using the equipment available at Institute of Medical Research and Medicinal Plant Studies.

\section{Plant material}

The leaves of $V$. thyrsiflora Baker (Verbenaceae) were collected at Melong, in the Littoral Region of Cameroon in November 2009, authenthification was performed by Mr. Nana who compared it with a Voucher Specimen (No 34861 HNC), in the Cameroon National Herbarium, Yaoundé.

\section{Extraction}

The extract was obtained by maceration of air-dried and powdered leaves of $V$. thyrsiflora $(3.0 \mathrm{Kg})$ with EtOH $(3 \times 15 \mathrm{~L}, 72 \mathrm{~h})$ at room temperature, to obtain a crude extract $(150 \mathrm{~g})$.

Phytochemical screening of secondary metabolites

The $V$. thyrsiflora leaves ethanol extract was also subjected to phytochemical analysis according to the methods of Harborne ${ }^{20}$ and Evans ${ }^{21}$.

\section{Experimental Animal}

Healthy adult male Wistar rats weighing 200-250 g were used in the present study. The animals were housed in clean grill cages and maintained in a well ventilated temperature controlled room at the animal house of Institute of Medical Research and Medicinal Plants studies, Yaoundé, Cameroon, with a constant $12 \mathrm{~h}$ light/dark schedule. The animals were fed with standard rat pellet diet and clean drinking water was made available ad libitum.

\section{Induction of diabetes}

Rats were fasted overnight (16h) before inducing diabetes with streptozotocin. Streptozotocin was prepared in freshly prepared sodium chloride solution $0.9 \%$ and was injected intraperitonially at a concentration of $55 \mathrm{mg} / \mathrm{Kg}$ body weight in a volume of saline of about $500 \mu \mathrm{l} / 200 \mathrm{~g}$ body weight by applying the protocol of Szkudelski ${ }^{22}$. Control rats were injected with saline solution only. The diabetic state was confirmed $72 \mathrm{~h}$ after streptozotocin injection. Threshold value of fasting blood glucose was taken as $\geq$ $200 \mathrm{mg} / \mathrm{dl}$. Diabetic rats were weighed, matched for body weight and divided into 5 groups consisting of 5 animals each.

Antihyperglycaemic effect of ethanol extract of $V$. thyrsiflora leaves on diabetic rats

The approval of the Institutional Animal Ethics Committee was obtained before starting the study. An International protocol for conducting experiments on animals were followed.

\section{Experimental design}

The Diabetic rats were divided into 5 groups with five rats each: (A, B, C and D). Group A rats received DMSO $3 \%$, those of group B and C were treated with ethanol extract of $V$. thyrsiflora at the doses of 200 and $300 \mathrm{mg} / \mathrm{Kg}$ body weight respectively, and Group D received glibenclamide $(10 \mathrm{mg} / \mathrm{Kg}$ body weight). Blood samples were collected before the commencement of treatment with the extract and then after, at $1 \mathrm{~h}, 3 \mathrm{~h}$ and $5 \mathrm{~h}$ intervals.

Oral Glucose Tolerance Test on normoglycemic rats This study was carried out on normal male rats with normal blood glucose level, according to the method of Schoenfelder et al., ${ }^{23}$. The animals were fasted for $16 \mathrm{~h}$ prior to the study. Five groups with 5 animals each were constituted and the animals received a dose of 3 $\mathrm{g} / \mathrm{Kg}$ of glucose by oral route $60 \mathrm{~min}$ after haven been treated with the extract as follows:

Group I: vehicle (DMSO 3\%; $10 \mathrm{ml} / \mathrm{Kg} \mathrm{b.} \mathrm{w,} \mathrm{negative}$ control),

Group II: water-ethanol extract (200 mg/Kg b.w), Group III: ethanol extract (300 mg/Kg b. w),

Group IV: ethanol extract (400 mg/Kg b. w)

Group V: glibenclamide (10 mg/Kg b. w), was served as positive control.

Blood was collected from the animals before administration of the extract (-60 min), and then after at $0,30,60,90$ and 150 min post administration.

\section{Blood Glucose Estimation}

Blood samples were obtained by tail prick and fasting blood glucose levels were estimated with a One Touch Ultra glucometer (Life Scan, Inc., Milpitas, CA, USA) in all animals. Blood glucose levels were expressed in $\mathrm{mg} / \mathrm{dL}$.

Dosage of phenolic compounds and antioxidants evaluation

Determination of Total phenolic content (TPC)

The ability of the extracts to reduce the phosphomolybdic-tungstate chromogene in Folin Ciocalteu with maximum absorbance at $760 \mathrm{~nm}$ (Total phenolic content, TPC) was assessed as earlier described by Vinson et al., ${ }^{24}$. Data were reported as mean \pm SD for triplicate measurements. Catechin was 
used as control and the results were expressed as $\mathrm{mg}$ Catechin equivalent/g (mg CE/g).

Determination of Total flavonoid content (TFC)

The Total Flavonoid Content (TFC) was measured as earlier described ${ }^{25}$. Total Flavonoid Content of the extract were expressed as mg Quercetin Equivalent/g (mg QE/g) through the calibration curve with quercetin. Data were reported as mean \pm SD for triplicate measurements.
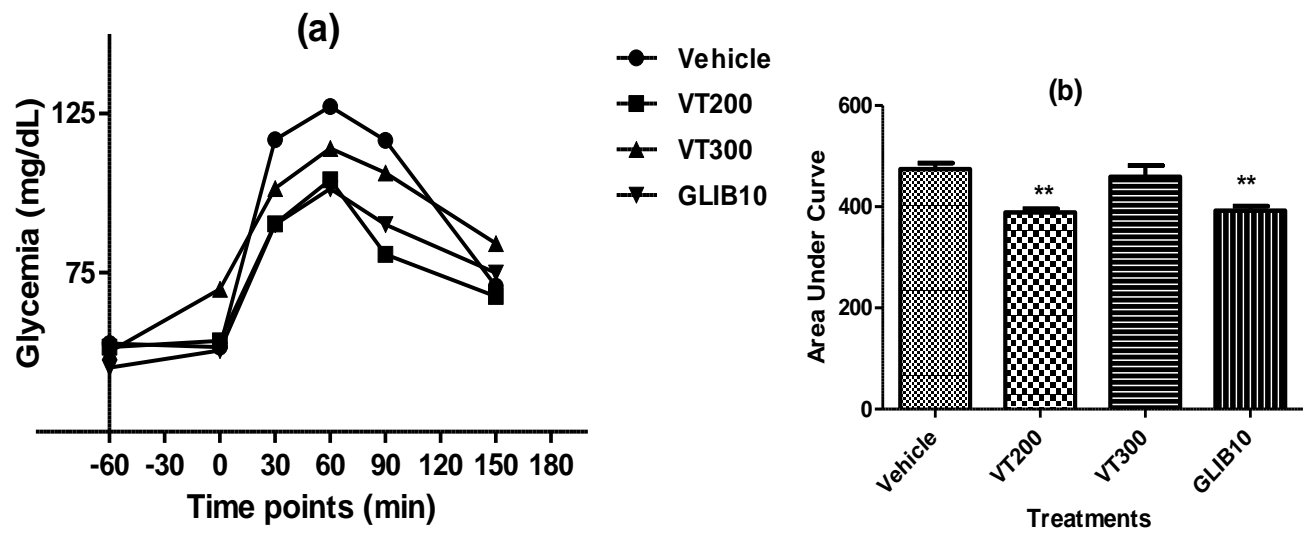

Figure 1: a. Effect of ethanol extract of $V$. thyrsiflora leaves on glycaemia during Oral Glucose Tolerance Test (OGTT) and b. Area under curve associated with this effect of ethanol extract of $V$. thyrsiflora leaves.

Data are expressed as means \pm S.D $(n=5) . * * p \leq 0.01$ compared with the corresponding value for vehicle control rats. VT200: V. thyrsiflora (200 $\mathrm{mg} / \mathrm{Kg}$ ); VT300: V. thyrsiflora (300 mg/Kg); Glib10: Glibenclamide (10 mg/Kg).

Determination of ferric reducing antioxidant power (FRAP) assay

The Ferric Reducing Antioxidant Power (FRAP) of an extract measures the ability of the extract to reduce ferric tripyridyltriazine to ferrous tripyridyltriazine, yielding a blue coloration with maximum absorbance at $593 \mathrm{~nm}$. FRAP assay was performed like previously described by Benzie and Strain ${ }^{26}$. The FRAP value was calculated and expressed as mg Catechin Equivalent/g (mg CE/g) based on a plotted calibration curve, using Catechin as standard, at a concentration ranging from 50 to $600 \mu \mathrm{mol}$.

DPPH free radical scavenging assay

The ability of the extract to scavenge free radicals by converting DPPH (purple in color) into di-phenyl hydrazine (yellow in color) was measured at $517 \mathrm{~nm}$ as earlier described ${ }^{27}$.

The percentage $(\%)$ radical scavenging effect (RSE) of extract was calculated as follows:

$$
\% \text { RSE }=\frac{A b s 1-A b s 2}{A b s 1} X 100
$$

Where Abs1 is the absorbance of the control (containing all reagents except for the extract), and Abs2 is the absorbance of plant extract (is the optical density in the presence of the extract). All tests were performed in triplicates. The parameter $\mathrm{IC}_{50}$ (concentration at which the DPPH radicals were scavenged by $50 \%)(\mathrm{mg} / \mathrm{mL})$ was also calculated. $\mathrm{IC}_{50}$ values were estimated from the $\%$ inhibition versus concentration plot, using a non-linear regression algorithm. The data was presented as mean values \pm standard deviation $(n=3)$.

\section{Statistical Analysis}

Results were expressed as mean \pm SD. Statistical analysis were carried out using one way Analysis of variance (ANOVA) followed by Dunnet test for comparison to vehicle control or followed by Newman-
Keuls Multiple Comparison Test for antioxidant parameters, using GraphPad Prism 5.03 software. A value of $p \leq 0.005$. $* \mathrm{p} \leq 0.05 ; * * \mathrm{p} \leq 0.01 ; * * * \mathrm{p} \leq 0.001$ was considered to be significant.

\section{RESULTS}

Phytochemical screening revealed that the ethanol extract of $V$. thyrsiflora leaves contained alkaloids, flavonoids, steroids, phenolics compound, saponosids, catechic tanins and anthraquinones (Table 1). The Area Under Curve (AUC) associated with the effect of ethanol extract of $V$. thyrsiflora leaves on Oral Glucose Tolerance Test (OGTT) in normoglycemic male rats was significantly decreased $(* * p \leq 0.01)$ at $200 \mathrm{mg} / \mathrm{Kg}$, when compared to vehicle control group $(474 \pm 26.93$ to $388.60 \pm 16.05)$, as well as in the group receiving glibenclamide at $10 \mathrm{mg} / \mathrm{Kg}$, where the AUC was decreased from $474 \pm 26.93$ to $392.50 \pm 19.45$ (Figure $1 b)$.

Table 1: Phytochemical screening of ethanol extract of $V$. thyrsiflora leaves.

\begin{tabular}{lc}
\hline $\begin{array}{l}\text { Phytochemical } \\
\text { constituents tested }\end{array}$ & Results \\
\hline Alkaloids & + \\
Flavonoids & +++ \\
Tri Terpenoids & - \\
Steroids & +++ \\
Phenolics compound & +++ \\
Saponosids & ++ \\
Catechic tanins & +++ \\
Anthraquinones & ++ \\
Glucosides & -
\end{tabular}

$(+)=$ indicates presence of phytochemicals and $(-)=$ indicates absence of phytochemicals. $+++=$ shows high concentration; $++=$ shows moderate concentration; $+=$ shows small concentration 

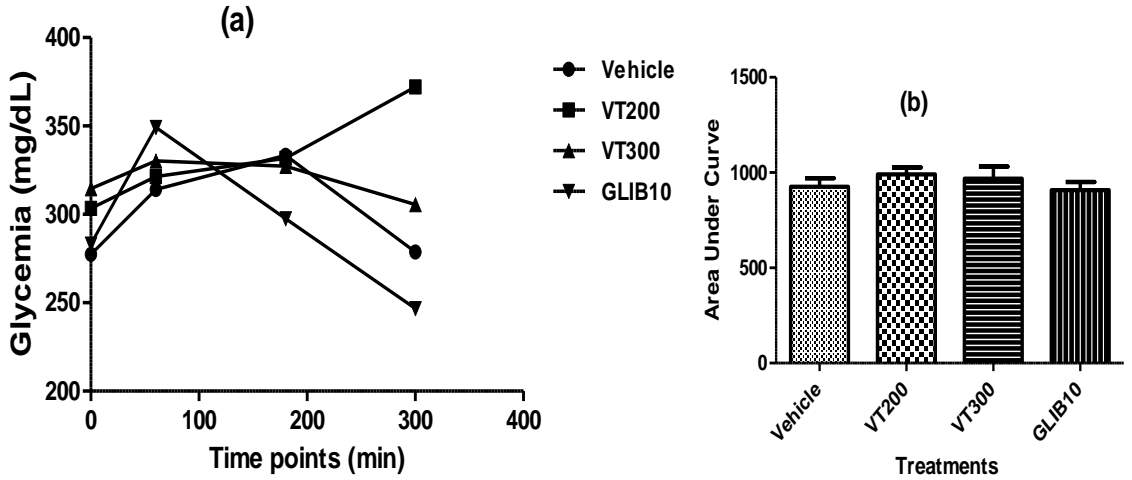

Figure 2: a. Effect of $V$. thyrsiflora ethanol extract on glycemia of STZ-induced diabetic rats; b. Area under curve associated with the effect of ethanol extract of $V$. thyrsiflora leaves on glycemia of STZ-induced diabetic.

Data are expressed as means \pm S.D $(\mathrm{n}=5)$. $p \leq 0.001$ compared with the corresponding value for vehicle control rats. VT200: V. thyrsiflora (200 $\mathrm{mg} / \mathrm{Kg})$; VT300: V. thyrsiflora $300 \mathrm{mg} / \mathrm{Kg})$; Glib10: Glibenclamide $(10 \mathrm{mg} / \mathrm{Kg})$.

The administration of ethanol extract of $V$. thyrsiflora leaves at $200 \mathrm{mg} / \mathrm{Kg}$ or $300 \mathrm{mg} / \mathrm{Kg}$ to diabetic rats didn't show any difference in the blood glucose level, according to the AUC associated with each group tested. Even glibenclamide didn't show a significant effect on lowering the high blood glucose level state induces by streptozotocin (Figure 2).

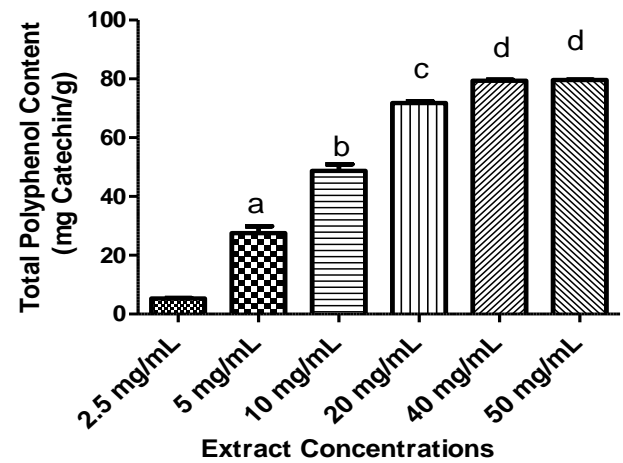

Figure 3: Total Polyphenol Content of ethanol extract of $V$. thyrsiflora.

Data are expressed as means \pm S.D $(n=3)$; a significantly different from $2.5 \mathrm{mg} / \mathrm{ml}$, b significantly different from $2.5 \mathrm{mg} / \mathrm{ml}$ and 5 $\mathrm{mg} / \mathrm{ml}$, c significantly different from $2.5 \mathrm{mg} / \mathrm{ml}, 5 \mathrm{mg} / \mathrm{ml}$ and 10 $\mathrm{mg} / \mathrm{ml}$, d significantly different from $2.5 \mathrm{mg} / \mathrm{ml}, 5 \mathrm{mg} / \mathrm{ml}, 10 \mathrm{mg} / \mathrm{ml}$ and $20 \mathrm{mg} / \mathrm{ml}$

The Total Polyphenol Content (TPC) appears to be significantly dose dependent on the concentrations of the extract, until $40 \mathrm{mg} / \mathrm{Kg} \quad(79.36 \pm 0.3717 \mathrm{mg}$ Catechin/g), where the TPC became stable and not different to that of $50 \mathrm{mg} / \mathrm{Kg}$ (Figure 3). The Total Flavonoid Content (TFC) evaluated in V. thyrsiflora ethanol extract showed a significant dose dependent increase when compared to $2.5 \mathrm{mg} / \mathrm{Kg}$. The content was the same at doses of $5 \mathrm{mg} / \mathrm{Kg}$ and $10 \mathrm{mg} / \mathrm{Kg}$ (Figure 4). The correlation between Ferric Reducing Antioxidant Power (FRAP) and Total Flavonoid Content (TFC) showed a very strong positive correlation (Pearson $\mathrm{r}=$ 0.9223 with $\mathrm{R}^{2}=0.8507, \mathrm{p}^{* *}=0.0088$ ) (Figure 5). The correlation between FRAP and TPC was significantly high $\left(\mathrm{p}^{* *}=0.0010\right)$ (Figure 6).

\section{DISCUSSION}

The aim of this work was to evaluate the antioxidant and the antihyperglycemic potential of the ethanol extract of $V$. thyrsiflora leaves. The phytochemical screening reveals that the ethanol extract of $V$. thyrsiflora leaves possesses alkaloids, flavonoids, steroids, phenolic compounds, catechic stanins, anthraquinones and saponosids in traces.

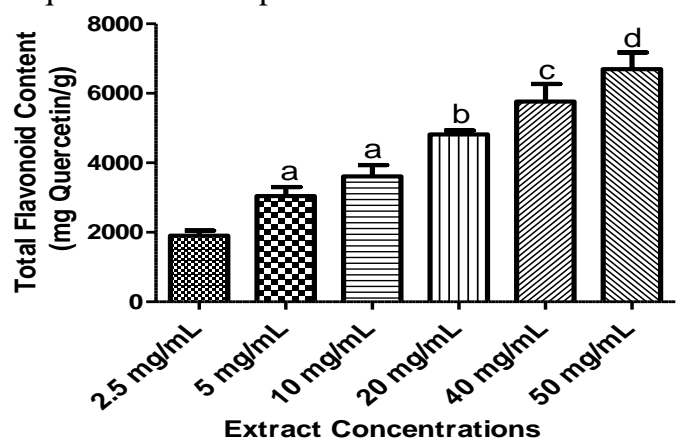

Figure 4: Total Flavonoid Content (TFC) of ethanol extract of $V$. thyrsiflora.

Data are expressed as means \pm S.D $(n=3)$; a significantly different from $2.5 \mathrm{mg} / \mathrm{ml}$, b significantly different from $2.5 \mathrm{mg} / \mathrm{ml}, 5 \mathrm{mg} / \mathrm{ml}$ and $10 \mathrm{mg} / \mathrm{ml}$, c significantly different from $2.5 \mathrm{mg} / \mathrm{ml}, 5 \mathrm{mg} / \mathrm{ml}, 10$ $\mathrm{mg} / \mathrm{ml}$ and $20 \mathrm{mg} / \mathrm{ml}$, d significantly different from $2.5 \mathrm{mg} / \mathrm{ml}, 5$ $\mathrm{mg} / \mathrm{ml}, 10 \mathrm{mg} / \mathrm{ml}, 20 \mathrm{mg} / \mathrm{ml}$ and $40 \mathrm{mg} / \mathrm{ml}$.

The evaluation of the effect of $V$. thyrsiflora ethanol leaves extract on hyperglycemic normal rats in OGTT showed that, the $200 \mathrm{mg} / \mathrm{Kg}$ dose was the most active to lower the AUC induced by glucose loaded in normal rats male $(* * \mathrm{p} \leq 0.01)$. Glibenclamide $(10 \mathrm{mg} / \mathrm{Kg})$, a widely used antidiabetic drug was effective to decrease the AUC observed in the vehicle group $(* * p \leq 0.01)$.

The results of OGTT in normal rats could be correlated with the ability of the extract to probably enhance the secretion of insulin in the likely manner of sulfonylureas and inhibit $\alpha$-glucosidases present in the border brush of the small intestine $e^{28,29}$. Enhanced tissue uptake of blood glucose induced by $V$. thyrsiflora might also be taken into consideration as an alternative possibility. In current study, the decrease in blood glucose at $200 \mathrm{mg} / \mathrm{Kg}$ and not at $300 \mathrm{mg} / \mathrm{Kg}$ could be explained by the presence of hyperglycemic compounds which have become the majority at this dose.

Some studies showed that, antagonistic relationship among phytochemicals would affect the efficacy of crude extracts as used in traditional medicine, like observed by Milugo et al., ${ }^{30}$ on antagonistic effect of alkaloids and saponin. 


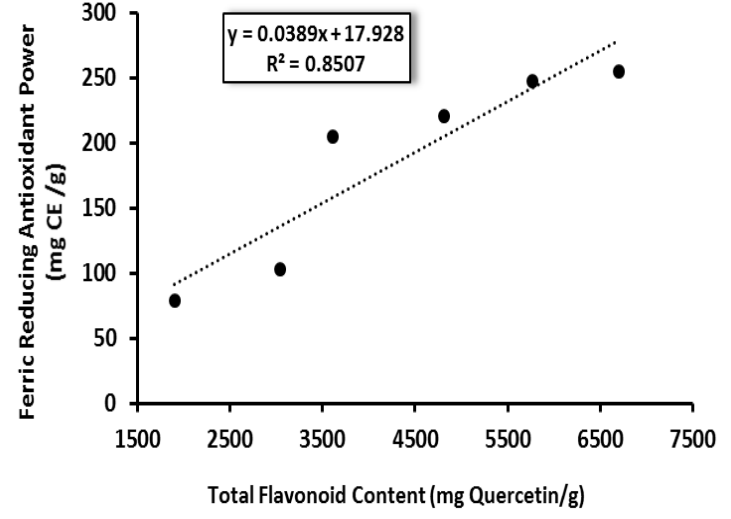

Figure 5: Correlation between FRAP and the total flavonoid content $(\mathrm{mg} \mathrm{QE} / \mathrm{g})$. (Pearson $\mathrm{r}=0.9223 ; \mathrm{R}^{2}=0.8507, p^{* *}=0.0088(p<0.01)$.

Furthermore, the results show that administration of the extract is associated with no effect on blood glucose level in STZ-diabetic rats. Since streptozotocin selectively destroys $B$-cells of the pancreas, we would expect the extract to exert no effect on plasma glucose concentrations in STZ diabetic rats if the mode of action is mediated through insulin production.

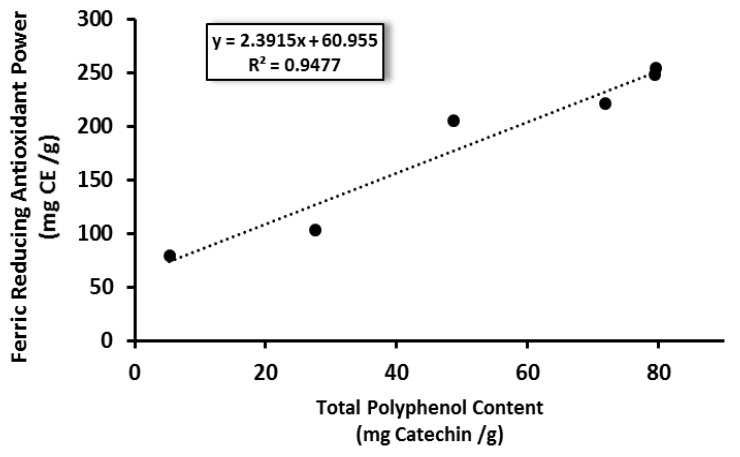

Figure 6: Correlation between FRAP and the total polyphenol content (mg QE/g).

(Pearson $\mathrm{r}=0.9735 ; \mathrm{R}^{2}=0.9477, p^{* *}=0.0010(p<0.01)$.

Furthermore, the observations in the present study indicate that the hypoglycaemic effect of the extract as well as that of glibenclamide were far more pronounced in OGTT rats than in STZ-diabetic rats. This result is probably in line with the early suggestion that glibenclamide was effective in moderately streptozotocin-induced diabetic animal and ineffective in severe diabetic rats ${ }^{31,32}$; the extract could act in the same way as glibenclamide. These observations taken together suggest that ethanol extract of $V$. thyrsiflora leaves has a potential in the management of acute hyperglycaemia. Antioxidant parameters showed a dose-dependent rise in the concentration of the extract. The TPC and the TFC showed a positive correlation with the FRAP test, which could suggest that this method would act through polyphenols and flavonoids. The Pearson correlation coefficient $\left(\mathrm{R}^{2}\right)$ is often used for measuring and describing the degree of linear regression between two continuous quantitative variables that are normally distributed. In current study, the $\mathrm{R}^{2}$ value of the correlation between the iron reduction technique "FRAP" (Ferric Reducing Antioxidant Power) and the Total Phenolic Content was equal to 0.9477 with $p^{* *}=0.0010$ and $\mathrm{R}^{2}=0.8507$ with $p^{* *}=0.0088$ for Total Flavonoid Content respectively. These results suggested that a great part of the antioxidant capacity of the ethanol extract of $V$. thyrsiflora leaves is attributed to the Total Polyphenol Content, mainly to flavonoid content in the extract, which have the hydrogen-donor ability to reduce iron. Similar studies suggested a linear relationship between antioxidant capacity and flavonoid contents of the plant extract ${ }^{33,34}$. The DPPH assay is often used to evaluate the ability of antioxidant to donate hydrogen or to scavenge free radicals. However, DPPH scavenging activity is best represented by $\mathrm{IC}_{50}$ value, defined as the concentration of the antioxidant needed to scavenge $50 \%$ of DPPH present in the test solution ${ }^{35}$. In current study $\mathrm{IC}_{50}$ was $65.97 \mathrm{mg} / \mathrm{ml}, \mathrm{R}^{2}=0.9945$ for the $V$. thyrsiflora leaves ethanol extract based on the log (inhibitor) vs normalized response - variable slope, which can be considered to be low antioxidant activity ( $\mathrm{IC}_{50}$ from 50.62 to $110.46 \mathrm{mg} / \mathrm{ml}$ ) according to the scale of Surinut et al., ${ }^{36}$; this might suggest that the antioxidant activity of this extract would not be mediated by donating hydrogen to scavenge free radicals but by the reduction of iron.

\section{CONCLUSION}

Based on the results of the present study, we conclude that the plant extract possesses antioxidant potential. The findings of the present study also suggest that $V$. thyrsiflora ethanol leaf extract could be a potential natural source of antioxidants and could have greater importance as therapeutic agent in preventing or slowing oxidative stress related degenerative diseases. However, this work is the first report which evaluates antihyperglycemic effect of ethanol extract of $V$. thyrsiflora leaves and its antioxidant potential. Further studies should be carried out to evaluate $\alpha$-amylase inhibitory and beta-glucosidase inhibitory activities isolate and identify active compounds, to understand the mechanism of action against hyperglycemia.

\section{AUTHOR'S CONTRIBUTION}

The manuscript was carried out, written, and approved in collaboration with all authors.

\section{ACKNOWLEDGEMENTS}

The authors extend their thanks and appreciation to the Institute of Medical Research and Medicinal Plant Studies (IMPM), Cameroon to provide necessary facilities for this work.

\section{CONFLICT OF INTEREST}

No conflict of interest associated with this work.

\section{REFERENCES}

1. Mabberley DJ. The plant-Book: A portable Dictionary of the Vascular Plants, $2^{\text {nd }}$ Edition. Cambridge University Press: Cambridge, U.K. 1997, 749.

2. Adjanohoun JE, Aboubakar N, Dramane K, Ebot ME, et al. Traditional Medicinal Pharmacopoeia: Contribution to ethnobotanical and floristics studies in Cameroon. CNPMS (Centre National de Production de Manuels Scolaires), Porto- Novo. 1996; 409.

3. Kubo I, Matsumto A, Hanke FJ Ayafor JF. Analytical droplet counter-current chromatography isolation of 20- 
hydroxyecdysone from Vitex thyrsiflora (Verbenaceae). J Chromat 1984; 321: 246-248. https://doi.org/10.1016/S0021-9673(01)90442-X

4. Kuruzum-Uz A, Stroch K, Demirezer LO, Zeeck A. Glucosides from Vitex agnus- castus. Phytochemistry 2003; 63: 959-964.https://doi.org/10.1016/S0031-9422(03)00285-1

5. Ono M, Nishida Y, Masuoka C, Li J-C, Okawa M, Ikeda T, Nohara T. Lignan Derivatives and a Norditerpene from the seesd of Vitex negundo. J Nat Prod 2004; 67: 2073-2075. https://doi.org/10.1021/np040102t

6. Chenchugari S, Karumanchi VR, Gottumukkala VS. Flavonoids, triterpenoids and a lignans from Vitex altissima. Phytochemistry 2005; 66: 1707-1712. https://doi.org/10.1016/j.phytochem.2005.05.008

7. Ono M, Yamamoto M, Yanaka T, Ito Y, Nohara T. Ten new labdane-type diterpenes from the fruit of Vitex rotundifolia. Chem. Pharm. Bull 2001; 49: 82-86.

8. Rasamison VE, Ranaivo-Harimanana L, Cao S, Pan E, Ratovoson F, Randriantafika F, Rakotondrajaona R, Rakotonandrasana S, Andriantsiferana R, Kingston D. A new labdanediterpene from Vitex cauliflora Moldenke from the Madagascar rainforest. Fitoterapia 2010; 81: 55-58. https://doi.org/10.15553/c2013v681a8

9. Kopa TK, Tane P, Wabo HK, Tala MF, Tchinda AT, Zofou $\mathrm{D}$, Tan N-H, Titanji VPK. In vitro antiplasmodial activity of the isolated compounds from the stem barks of Vitex thyrsiflora. Comptes Rendus Chimie 2016; 7: 807-811. https://doi.org/10.1016/j.jep.2011.11.036

10. Devi PR, Kumari SK, Kokilavani C. Effect of Vitex negundo leaf extract on the free radicals scavengers in complete Freund's adjuvant induced arthritic rats. Indian $\mathrm{J}$ Clin Biochem 2007; 22:143-147. https://doi.org/10.1007/BF02912899

11. Rabeta MS, An Nabil Z. Total phenolic compounds and scavenging activity in Clitoria ternatea and Vitex negundo Linn. Int Food Res J 2013; 20(1): 495-500.

12. Duthie GG, Duthie SJ, Kyle JA. Plant polyphenols in cancer and heart disease: implications as nutritional antioxidants. Nutr Res Rev 2000; 13:79 - 106. https://doi.org/10.1079/095442200108729016

13. Blokhina O, Virolainen E, Fagerstedt KV. Antioxidants, oxidative damage and oxygen deprivation stress: a review. Ann Bot 2003; 91:179 - 94 https://doi.org/10.1093/aob/mcf118

14. Myburgh KH. Polyphenol supplementation: benefits for exercise performance or oxidative stress? Sports Med 2014; 1: 57 - 70. https://doi.org/10.1007/s40279-014-0151-4

15. Bors, W, Michel, C. Antioxidant capacity of flavanols and gallate esters: pulse radiolysis studies. Free Radic Biol Med 1999; 27(11), 1413-1426. https://doi.org/10.1016/S0891-5849(99)00187-2

16. Sousa CMM, ReSH, Vieira-Jr GM, Ayres MCC, Costa CLS, Araújo DS, et al. Fénoistotais e atividade antioxidante de cinco plantas medicinais. Quim Nova 2007; 30:351- 355.

17. Lacopini P, Baldi M, Storchi P, Sebastiani L. Catechin, epicatechin, quercetin, rutin and resveratrol in red grape: content, in vitro antioxidant activity and interactions. J Food Compos Anal 2008; 21: 589-598.

https://doi.org/10.1016/j.jfca.2008.03.011

18. Matough FA, Budin SB, Hamid ZA, Alwahaibi N, Mohamed $\mathrm{J}$. The role of oxidative stress and antioxidants in diabetic complications. Sultan Qaboos Univ Med 2012; 12(1):5-18. Epub 2012 Feb 7. https://doi.org/10.12816/0003082

19. Jayaraman R, Subramani S, Sheik Abdullah SH, Udaiyar M. Antihyperglycemic effect of hesperetin, a citrus flavonoid, extenuates hyperglycemia and exploring the potential role in antioxidant and antihyperlipidemic in streptozotocin-induced diabetic rats. Biomed Pharmacother 2018; 97:98-106. https://doi.org/10.1016/j.biopha.2017.10.102

20. Harborne JB. Phytochemical Methods - A Guide to Modern Techniques of Plant Analysis; Chapman and Hall: London, UK, 1998. https://doi.org/10.1007/978-94-009-5570-7

21. Evans WC. Trease and Evans Pharmacognosy, $15^{\text {th }}$ Edition, London, W.B. Saunders 2002.

22. Szkudelski T. The mechanism of alloxan and streptozotocin action in beta cells of the rat pancreas. Physiological Res 2001; 50: 537-546. PMID: 11829314

23. Schoenfelder T, Cirimbelli TM, Citadini-Zanette V. Acute effect of Trema micrantha (Ulmaceae) on serum glucose levels in normal and diabetic rats. J Ethnopharmacol 2006; 107: 456-459. https://doi.org/10.1016/j.jep.2006.07.027

24. Vinson JA, Su X, Zubik L, Bose P. Phenol antioxidant quantity and quality in foods: fruits. J Agric Food Chem 2001; 49:5315-5321. https://doi.org/10.1021/jf0009293

25. Chang L, Yen W, Huang S, Duh P. Antioxidant activity of sesame coat. Food Chem 2002; 78: 347-354 https://doi.org/10.1016/S0308-8146(02)00119-X

26. Benzie IFF, Strain JJ. The ferric reducing ability of plasma (FRAP) as a measure of antioxidant power: The FRAP assay. Anal Biochem 1996; 239: 70-76. https://doi.org/10.1006/abio.1996.0292

27. Blois MS. Antioxidant Determinations by the use of a stable free radical. Nature 1958; 181: 1199-1200. https://doi.org/10.1038/1811199a0

28. Tang LQ, Wei W, Chen LM, Liu S. Effects of berberine on diabetes induced by alloxan and a high-fat/high cholesterol diet in rats. J Ethnopharmacol 2006; 108(1): 109-115. https://doi.org/10.1016/j.jep.2006.04.019

29. Lenzen S. The mechanisms of alloxan-and streptozotocininduced diabetes. Diabetol 2008; 51(2): 216-226. https://doi.org/10.1007/s00125-007-0886-7

30. Milugo TK, Omosa LK, Ochanda JO, Owuor BO, Wamunyokoli FA, Oyugi JO, Ochieng JW1. Antagonistic effect of alkaloids and saponins on bioactivity in the quinine tree (Rauvolfia caffrasond.): further evidence to support biotechnology in traditional medicinal plants. BMC Complement Altern Med 2013; 13: 285. https://doi.org/10.1186/1472-6882-13-285

31. Ivorra MD, Paya M, Villar A. Hypoglycaemic and insulin release effects of tormentic acid: A new hypoglycaemic natural product. Planta Med 1988; 54: 282-286. https://doi.org/10.1055/s-2006-962433

32. Sharma SR, Dwivedi SK, Swarup D. Hypoglycaemic potential of Mangifera indica leaves in rats. Int $\mathbf{J}$ Pharmacogn 1997; 35 (2): 130-133. https://doi.org/10.1076/phbi.35.2.130.13276

33. Apak R, Gorinstein S, Böhm V, Schaich KM, Özyürek M, Güçlü K. Methods of measurement and evaluation of natural antioxidant capacity/activity (IUPAC Technical Report). Pure Appl Chem 2013; 85:957-998. https://doi.org/10.1351/PAC-REP-12-07-15

34. Nyunai N, Yaya AJG, Tabi TGN, Tchamgoue AD, Ngondé MC, Minka CSM. Anti-hyperglycemic and Antioxidant Potential of Water-Ethanol Extract of Musanga cecropioides Stem Bark. Int J Pharm Sci Drug Res 2016; 8(1): 43-49. https://doi.org/10.25004/IJPSDR.2016.080107

35. Karagözler AA, Erdağ B, Emek YÇ, Uygun DA. Antioxidant activity and proline content of leaf extracts from Dorystoechas hastata. Food Chem 2008; 111 (2):400-407. https://doi.org/10.1016/j.foodchem.2008.03.089

36. Surinut P, Kaewsutthi S, Surakarnkul R. Radical scavenging activity in fruit extracts. Acta Hortic 2005; 679, 201-203. https://doi.org/10.17660/ActaHortic.2005.679.25 